\begin{tabular}{|l|l|l||}
\hline \multicolumn{2}{|c|}{ PublisherInfo } \\
\hline \hline PublisherName & $:$ & BioMed Central \\
\hline \hline PublisherLocation & $:$ & London \\
\hline \hline PublisherImprintName & $:$ & BioMed Central \\
\hline \hline
\end{tabular}

\title{
African cows
}

\begin{tabular}{|l|c|l||}
\hline \multicolumn{2}{|c|}{ ArticleInfo } \\
\hline \hline ArticleID & $:$ & 4451 \\
\hline \hline ArticleDOI & $:$ & $10.1186 /$ gb-spotlight-20020415-01 \\
\hline \hline ArticleCitationID & $:$ & spotlight-20020415-01 \\
\hline \hline ArticleSequenceNumber & $:$ & 117 \\
\hline \hline ArticleCategory & $:$ & Research news \\
\hline ArticleFirstPage & $:$ & 1 \\
\hline \hline ArticleLastPage & $:$ & 2 \\
\hline \hline & & RegistrationDate : 2002-4-15 \\
\hline ArticleHistory & $:$ & OnlineDate \\
\hline \hline ArticleCopyright & $:$ & BioMed Central Ltd2002-4-15 \\
\hline \hline ArticleGrants & $:$ & \\
\hline \hline ArticleContext & $:$ & 130593311 \\
\hline \hline
\end{tabular}




\section{Jonathan B Weitzman}

Email: jonathanweitzman@hotmail.com

In the April 12 Science, Hanotte et al. describe efforts to define the genetic history of African cattle pastoralism, their origins and migrations (Science 2002, 296:336-339). Hanotte et al. performed a continent-wide sampling of indigenous African cattle including 50 populations from 23 countries. They analyzed cow samples using 15 autosomal microsatellite markers to calculate principal component values and to construct interpolation maps. Hanotte et al.present extensive statistical analysis of the cross-continent variation; they conclude that African cattle originate from the domestication of wild cows within the continent. But they found evidence for Near-East and European genetic influences, and suggest that cattle migration paths spread to southern regions via an eastern route.

\section{References}

1. Science, [http://www.sciencemag.org]

2. Ancient DNA suggests a recent expansion of European cattle from a diverse wild progenitor species. 